\title{
Challenges Faced By Small, Medium And Micro Enterprises In The Nkonkobe Municipality
}

Tendai Chimucheka, University of Fort Hare, South Africa

Fortunate Mandipaka, University of Fort Hare, South Africa

\begin{abstract}
This study investigated the challenges that are faced by entrepreneurs in the Nkonkobe Municipality in Eastern Cape Province of South Africa and the objectives were to identify and suggest solutions for the challenges.

This study followed a qualitative research design and in-depth interviews were used to gather data from the respondents. Small, Micro and Medium Enterprises (SMMEs) owners and managers in the Nkonkobe Municipality were the target population. A sample of thirty respondents was drawn using purposive sampling method. Most of the respondents who participated in the study were from the agricultural industry, trading sector, and the arts and crafts industry.

The challenges identified as impediments to the establishment, survival and growth of these SMMEs include lack of networking opportunities, lack of access to finance and inadequate government support. Recommendations were suggested to the SMME owners and managers, government agencies and the local municipality.
\end{abstract}

Keywords: SMMEs; Challenges; Resources; Entrepreneurship; Education

\section{INTRODUCTION}

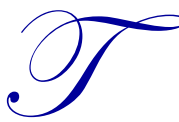

he Small, Micro and Medium Enterprises (SMMEs) sector is touted as an economic engine for many countries. Researchers in the field of entrepreneurship agree that this sector is crucial for economic growth, employment creation, poverty reduction and reducing levels of inequality. This sector is very crucial and plays a significant role in marginalised and rural provinces, such as the Eastern Cape Province of South Africa where the majority of people depend on government grants. Unemployment, poverty and inequality levels are also very high in this province. It is as a result of the role played by SMMEs that the South African government has also called for support of these businesses and for novice entrepreneurs, particularly in rural areas (Fatoki \& Smit, 2011).

It remains regrettable that despite the role played by the SMMEs sector and the support that they get in South Africa, more than 70 percent of these ventures still fail within three years after being established (Biyase, 2009; Fatoki \& Smit, 2011). The high failure rates of SMMEs in South Africa can be attributed to the challenges faced by these small businesses and also lack of support from key stakeholders.

Effective support can only be rendered to these business owners and managers only if the prospective support providers have a clear understanding of the challenges faced by SMMEs. There is need for solutions to reduce the continuing high failure and underperformance rates in the SMMEs sector for the country to reap some of the benefits that come as a result of having an effective SMME sector. 


\section{PROBLEM STATEMENT}

Researchers in the field of entrepreneurship agree that SMMEs play a significant role in the economy. In South Africa, they are crucial for they help reduce the socio-economic challenges. It is, however, disappointing that the majority of these SMMEs continue to fail within a very short time. Their unacceptable high failure rates are as a result of the numerous challenges they face. It is therefore important to investigate and propose solutions to these challenges. Thus, the objectives of this study were to 1) investigate the challenges faced by entrepreneurs in the Nkonkobe Municipality, South Africa, and 2) suggest solutions to the identified challenges.

\section{SIGNIFICANCE OF THE STUDY}

This study is important for the effective formulation and implementation of policies that seek to develop the SMME sector. There is need for a clear understanding of the challenges hampering the growth and development of these small ventures if meaningful solutions are to be implemented. Although some research has been conducted in the SMME sector, it remains important to also investigate challenges faced by entrepreneurs operating SMMEs in the Eastern Cape Province of South Africa.

\section{LITERATURE REVIEW}

Literature review in this study will be subdivided into empirical literature and theoretical framework.

\subsection{Empirical Literature}

Literature reveals that challenges faced by SMMEs in developing countries have been learned to be the same to those of their counterparts in developed countries. The only difference between the challenges that confront SMMEs in developing and developed countries is the fact that the magnitude of their differences weighs more negatively for developing countries. Past studies have shown that a number of factors hinder the survival and growth of SMMEs.

The growth and survival of SMMEs are threatened by impediments that may exist in the operations and management functional areas of the business. A number of studies have identified factors, such as inexperience in the field of business, lack of technical knowledge, poor managerial skills, lack of planning skills, and lack of market research skills, as the main challenges hindering the success of SMMEs in developing countries (Baron \& Shane, 2007; Olutunla \& Obamuyi, 2008; Schwartz \& Hornych, 2010). Additionally, past studies have revealed that entrepreneurs with technical backgrounds may find challenges in managing operations and management functional areas of the business (Omerzel \& Antonic, 2008; Mbonyane \& Ladzani, 2010). It is also noticed that poor bookkeeping practices often make it difficult for SMMEs to be successful (Tushabomwe-Kazooba, 2006).

The survival and growth of SMMEs may also be hindered by environmental challenges, such as competition, unfriendly business environment, government regulatory and law issues and the state of the economy. Urban and Naidoo (2012) posits that the key challenge facing SMMEs in most developing countries is meeting both local and global competition from well-established businesses. SMMEs' competitiveness in developing countries is hindered because of a lack of human resource and development skills and access to adequate finance. According to Fumo \& Jabbour (2011), regulatory and legal issues are also challenges that SMMEs are facing. Small business practitioners may often not understand the law and, as a result, may end up paying penalties and fines. Previous studies (Martinsons, 2008; Okpara, 2011) have also noted that the lack of macro-economic policies and other forms of regulatory policies in developing countries hinder the success of SMMEs.

Moreover, SMMEs often have difficulties in accessing appropriate technologies and information (Schwartz \& Hornych, 2010). Ocloo, Akaba, \& Worwui-Brown (2014) argue that, in most cases, SMMEs utilise foreign technology that they lease or share ownership with other business counterparts. Mutula and Van Brakel (2007) are of the view that even though internet is available, its continued use in SMMEs is hindered by lack of electricity, mainly in rural areas and load shading in urban areas. Another challenge faced by SMMEs is limited access to market information and only a small number of small businesses have access to communication technologies such as telephones and fax machines (Oreku, Kimeli \& Mtenzi, 2009). 
Other acknowledged challenges that negatively affect small business development include lack of access to equipment, corruption, poor infrastructure, and access to international markets (Martin \& Staines, 2008; Lather, 2009; Bowen, Morara \& Mureithi, 2009; Abor \& Quartey, 2010). Kim (2011) states that lack of support services also hinders SMMEs' efforts to improve their management because consulting firms are often not equipped with appropriate cost-effective management solutions for SMMEs. Moreover, even though there are numerous institutions providing training and advisory services to SMMEs, there is still a skills gap in the SMME sector as a whole (Ahmed, 2009). This is because small business owners cannot afford the high cost of training and advisory services and others do not see the need to upgrade their skills due to complacency.

\subsection{Theoretical Framework}

The finance gap theory and the resource dependency theory will form the theoretical framework of this study.

\subsubsection{Finance Gap Theory}

The finance gap theory, as postulated by Bolton (1971), states that the components-knowledge gap and supply gap are the two sets of challenges faced by SMMEs. Bolton (1971) points out that SMMEs lack knowledge about available sources of external finance and that once these are determined, SMMEs have trouble satisfying the loan requirements from the external financier. Furthermore, external financiers do not understand the entrepreneur and their small business venturing (Bolton, 1971). This means that the only possible way that SMMEs can raise capital is through personal savings, friends, and family members. Additionally, since both their venture capital and sales value are small as compared to operating costs, they face challenges in maintaining the business resulting in eventual collapse of the SMMEs.

\subsubsection{Resource Dependency Theory}

The central premise of the resource dependency theory by Pfeffer and Salancik (1978) is the relationship between a firm and a set of stakeholders in the business environment. Nevertheless, the focus is on the firm's ability to access resources from other stakeholders in the business environment and describes how resource scarcities force firms to pursue new innovations that use alternative resources. The theory further postulates that SMMEs' survival depends on the firm's ability to acquire and retain resources from stakeholders within the task environment (Dunn, 2008). The theory suggests that firms must aim to reduce or increase its level of dependency from other external actors through alliance and joint ventures. In addition, the theory can be interpreted to explain how SMMEs might pursue direct and indirect markets of internationalisation to reduce exposure to home markets which may be undesirable due to high market saturation, production costs and instead focus on other more attractive national markets (Guo \& Acar, 2005).

\section{METHODOLOGY}

Both primary and secondary data were used in this study. Secondary data were gathered by way of a thorough literature review and to gather primary data, the study followed a qualitative research design. The purpose of conducting qualitative research was to gain insights into the perceptions, feelings and attitudes of entrepreneurs on the challenges that they face. In-depth interviews were conducted to gather primary data from the respondents. Small, Micro and Medium Enterprise (SMMEs) owners and managers in the Nkonkobe Municipality were the target population. A sample of thirty respondents was drawn using purposive sampling method. Most of the respondents are managers or owners of SMMEs in the agricultural industry, trading sector and the arts and crafts industry.

\section{RESULTS AND DISCUSSION}

This section outlines the challenges faced by SMMES in running their businesses. Data collected from interviews are analysed question by question. 
The survey sought to understand whether SMMEs have network opportunities that aid them with easy access to operations resources required for day-to-day running of the business. Sixty-seven percent of the respondents had no idea of the network opportunities available to them, whereas 33 percent do not spend more time on social activities that assist them in obtaining loans from commercial banks. The findings of the study are consistent with those of Chua, Chrisman, Kellermanns \& Wu (2011) who argued that most SMMEs, given their small size and lack of resources, are not able to make use of social capital to gain debt finance. Additionally, these results also refute the study conducted by Talavera, Xiong, \& Xiong (2010) to investigate the impact of social capital on access to bank financing. The results indicate that entrepreneurs who spend more time on social activities are more likely to obtain loans from commercial banks.

The study further sought to investigate the extent to which government's support of SMMEs was adequate in promoting the sustainability of these ventures. The findings reveal that a total of 23 percent reported that they were not aware of the government support centres or initiatives of supporting the businesses that are managed and operated by SMMEs. Seventy-seven percent indicated that they had once received support from the government and went further to highlight that the government support they received was inadequate. The results of this study are also consistent with literature. Hussain, Millman \& Matlay (2006) argue that even though governmental support is essential for SMMEs during the start-up phase, most of them do not get adequate government support.

When questioned on whether they have access to debt finance, all SMMEs were of the view that access to finance was one of their greatest challenges. They went on to point out that commercial bank were reluctant to offer loans to them because they are not confident in their abilities to run the businesses as well as the fact that most SMMEs do not have collateral security. These findings are supported by literature in that Piperopulos (2010) indicated that in a number of studies, researchers have found that ethnic minority businesses have never used or had access to business and financial support from banks and other financial institutions and thus had to rely on personal savings and ethnic social resources. Olawale \& Garwe (2010), in their study on the impact of gender on SMME characteristics and access to debt finance in South Africa, also highlighted that access to debt finance is a barrier to SMMEs' success.

Further analysis indicated that 38 percent of the respondents had a good business location and a total of 62 percent of the respondents' businesses were poorly located. These findings are consistent with the works of Ejembi and Ogiji (2007) who revealed that infrastructure (poor location) is a barrier for SMME growth, as the quality of this can affect the growth prospects of SMMEs, especially in developing countries, because many of these countries suffer from a deplorable lack of basic infrastructure such as transport, telecommunications, and electricity.

More than 55 percent of the respondents indicated that registration was a great challenge. They also highlighted that it was not easy for them to obtain operating licenses. This challenge can fuel other problems for a business cannot be legitimate if it is not registered; hence, banks will not fund such an enterprise. These are some of the macro-environmental challenges that affect SMMEs (Brink, Cant \& Lighthelm, 2003).

Respondents indicated that there is low demand for the commodities they offer and they attributed this to high poverty levels in the area and high competition from bigger and well-established businesses. This is in line with the findings of van Scheers (2011) who also found that SMMEs face market-related challenges. Very few respondents had an idea of how they can create demand for their products and fight completion from rivals, which is a clear indication of lack of innovative ideas or entrepreneurial orientation.

Lack of experience, skills and knowledge was also identified as a challenge hampering the success of SMMEs in Nkonkobe Municipality. More than 40 percent of the respondents agreed that they had neither experience nor skills needed to run the ventures they are operating. This may also be a root cause for many other challenges that SMME operators complain about. If SMMEs are equipped with the right entrepreneurial or managerial competencies, they are most likely to succeed. 


\section{CONCLUSION AND RECOMMENDATIONS}

The aim of this study was to investigate the challenges faced by SMMES in the Nkonkobe Municipality, South Africa. An extensive literature review on the challenges faced by SMMES was done. From the survey results, it can be concluded that SMMEs face a lot of challenges in the business world. Most respondents stressed that the challenges they face hinder the survival and growth of their ventures. Based on the findings discussed in this paper, the following recommendations can be put forward to SMME owners and managers, as well as government agencies that assist SMMEs in South Africa.

To curb some of the challenges experienced by SMMES, as revealed by this study, entrepreneurship education and training is required. This is important since most SMMEs lack managerial and entrepreneurial competences. Thus, the government should strive to improve intellectual capacity among SMMEs on entrepreneurship education by expanding and strengthening tertiary education particularly in SMMEs development and project management. The levels of managerial and skill competences can also be improved by encouraging SMMEs to make use of programmes offered by government agencies.

It is also suggested that SMMEs should participate in networking colloquiums where they share their testimonies on business success, challenges they are facing to sustain or grow their businesses and come upon with possible solutions. Although, the government may be making efforts in dealing with the reluctance of commercial banks to offer SMMEs loans because they do not have collateral security, the government could assist by developing a supporting legal and regulatory framework that protects SMMEs from high interest and providing collateral to banks.

An effective legal and regulatory framework promotes competition by avoiding excessive restrictive licensing requirements and allows international and regional banks with better SMME-lending tools to enter the market. In addition, to curb the problem of collateral and lending issues, it is also recommended that policymakers and SMMEs consider the Grameen Bank-type model (GBM) which is based on the voluntary formation of small groups of underprivileged people and is meant to provide loans to those SMMEs without collateral, which is normally a hindrance to access finance by small businesses. This will help ease some of the challenges faced by SMMEs as they will then work together in solving them.

It is also advised that the government should promote SMMEs owned and managed by women because experience across different developed markets has shown that women have a better repayment record and yield a higher cross sell ratio for financial institutions.

SMMEs are recommended to adopt information and communication technologies in their businesses because the development of information and communication technology is central, not only for production but also for trade facilitation in both local and international markets.

By all means, the government should strive to do everything possible to improve the business environment in which SMMEs operate through improving infrastructure, thus road networks, buildings and communication technologies. The environments should be established in such a way that they promote or allow for new enterprises to emerge, existing ones to grow, and the large and small enterprises to coexist by supporting one another.

\section{AUTHOR INFORMATION}

Tendai Chimucheka is a lecturer at the University of Fort Hare in the department of Business Management. His research areas include Entrepreneurship and Small Business Management, Strategic Management, Financial Management, Marketing Management, and Business Economics. Email: tenchims@gmail.com.

Fortunate Mandipaka (Hons) is a Masters Candidate at the University of Fort Hare, South Africa. She is an emerging researcher interested in researching in areas of entrepreneurship, food security, and contemporary marketing practices, and she is well-versed in both qualitative and quantitative research techniques. Email: fmandie@gmail.com. 


\section{REFERENCES}

Abor, J., \& Quartey, P. (2010). Issues in SME development in Ghana and South Africa. International Research Journal of Finance and Economics (39), pp. 218-228.

Ahmed, S. (2009). "Microfinance institutions in Bangladesh: achievements and challenges", Managerial Finance, 35(12), 999-1010.

Baron, R. A., \& Shane, S. A. (2007). Entrepreneurship: A Process Perspective, 2 Ed., Mason, OH: Thomson SouthWestern.

Biyase, L .(2009). DTI to look at how crisis hurts small enterprises. Available from:www.busrep.co.za/index.php?fSectionId=561\&fArticleId=4947848 [Accessed: 12/08/2014].

Bolton Committee Report. (1971). Report of the Commission of Inquiry on Small Firms, Chaired by J. E. Bolton, Cmnd 4811, HMSO, London.

Bowen, M., Morara, M., \& Mureithi, M. (2009). Management of business challenges among small and micro enterprises in Nairobi, Kenya. KCA Journal of Business Management, 2(1), 16-31.

Brink, A.,Cant, M., \& Ligthelm, A. (2003). Problems experienced by small businesses in South Africa. $16^{\text {th }}$ Annual Conference of Small Enterprises Association of Australian and New Zealand. 28 September - 1 October 2003. University of Ballarat. Ballarat, Australia.

Chua, J. H, Chrisman, J. J., Kellermanns, F. W., \& Wu, Z. (2011). Family involvement and new venture debt financing. $J$ of Bus Vent, 26(4): 472-488.

Dunn, J. C. (2008). The dimensionality of remember-know task: A state trace analysis. Psychological Review, 115:426-446.

Ejembi, S. A., \& Ogiji, P. (2007). "A comparative analysis of risks and returns of running small/medium and micro enterprises in North and Central Nigeria", Journal of Social Science, Vol. 15 No. 1, pp. 7-15.

Fatoki, O. O., \& Smit, AVA. (2011). Constraints to credit assess by new SMEs in South Africa: A supply-side analysis. African Journal of Business Management (AJBM), Vol. 5 No. 4, pp.1413-1425.

Fumo, N. D. G., \& Jabbour, C. J. C. (2011). Barriers faced by MSEs: Evidence from Mozambique, Industrial Management \& Data Systems, 111 (6), pp. 849-868.

Guo, C., \& Acar, M. (2005). "Understanding Collaboration Among Nonprofit Organizations: Combining Resource Dependency, Institutional, and Network Perspectives", Nonprofit and Voluntary Sector Quarterly, 34(3): 340-361.

Hussain, J., Millman, C., \& Matlay, H. (2006). SME financing in the UK and in China: a com-parative perspective. Journal of Small Business and Enterprise Development 13 (4), 584-599.

Kim, Y. (2011). SMEs in Africa: Challenges and the role of Government for the future, (Online). Available:http://www.consultancyafrica.com/index.php?option=com_content\&view=Article\&id=906;smes in-\%201frica-challenges=and-the-role-of-government-for-the-future $\&$ catid=58:asiadimensionsdiscussions\%20papers\&itemid=264: Accessed 20 June, 2014.

Lather, A. S. (2009). Measuring the ethical quotient of corporations: The case of small and medium enterprises in India. Forum on Public policy, Spring, 1-15.

Martin, G., \& Staines, H. (2008). Managerial competencies in small firm [online].Available:http://www.emraldinsight.com/insight/viewcontentitem.do?contenttype Accessed: 20 June, 2014].

Martinsons, M. G. (2008). Relationship-based e-commerce: Theory and evidence from China. Information Systems Journal, 18(4), 331-356.

Mbonyane, B., \& Ladzani, W. (2010). Factors that hinder the growth of small businesses in South African townships. Eur. Bus. Rev. 23(6):550-560.

Mutula, S. M., \& Van Brakel, P. (2007). E-readiness of SMEs in the ICT sector in Botswana with respect to information access. Electronic library 24(3):402-417.

Ocloo, C. E., Akaba, S., \& Worwui-Brown, D. K. (2014). Globalization and Competitiveness: Challenges of Small and Medium Enterprises (SMEs) in Accra, Ghana. International Journal of Business and Social Science Vol. 5(4).

Okpara, J. (2011). Factors constraining the growth and survival of SMEs in Nigeria Implications for poverty alleviation. Management Research Review, 34(2), 156-171.

Olawale F, Garwe, D. (2010). Obstacles to the growth of new SMEs in South Africa: A principal component analysis approach. Afr. J. Bus. Man. 4(5):1993-8233. 
Olutunla, G. T., \& Obamuyi, T. M. (2008). “An Empirical Analysis of Factors Associated with the Profitability of Small and Medium Enterprises in Nigeria”, African Journal of Business Management, Vol.2 (x), pp. 195200.

Omerzel, D. G., \& Antoncic, B. (2008). "Critical entrepreneur knowledge dimensions for the SME performance", Industrial Management \& Data Systems, vol. 108, issue 9, pp. 1182-1199.

Oreku, G. S., Li, J., Kimeli, K., \& Mtenzi, F. (2009). State of Tanzania e-readiness and e-commerce: overview. Information Technology for Development 15(4):302-311.

Pfeffer, J., \& Salancik, R. G. (1978). The External Control of Organizations: A Resource Dependence Perspective. New York: Harper \& Row Publishers.

Piperopoulos, P. (2010). Ethnic minority businesses and immigrant entrepreneurship in Greece. Journal of Small Business and Enterprise Development, 17(1): 139-158.

Pool, P. W., Parnell, J. A., Spillan, J. E., Carraher, S., \& Lester, D. L. (2006). Are SMEs Meetings the Challenge of Integrating E-commerce into their Businesses? A Review of the Development, Challenges and Opportunities. International Journal Information Technology and Management, 5(2/3), pp.97-113.

Schwartz, M., \& Hornych, C. (2010). Cooperation patterns of Incubator firms and the impact of Incubator specialization: Empirical evidence from Germany. Technovation 30, 485-495.

Talavera, O., Xiong, L., \& Xiong, X. (2010). Social Capital and Access to Bank Financing: The Case of Chinese Entrepreneurs. From <http://www.uea.ac.uk/menu/ depts/eco/research/RePEc/uea/papers_pdf/UEAAFE019.pdf >: Accessed on 20 June, 2014.

Tushabomwe-Kazooba, C. (2006). "Causes of small business failure in Uganda: a case study from Bushenyi and Mbarara Towns", African Studies Quarterly, Vol. 8 No.4.

Urban, B., \& Naidoo, R. (2012). Business sustainability: empirical evidence on SME operational skills in South Africa. Journal of Small Business and Enterprise Development, 19 (1): 146-163.

Van Scheers, L. (2011). SMEs' marketing skills challenges in South Africa. African Journal of Business Management, 5(13):5048-5056. 


\section{NOTES}

